\title{
Development of an Eigenvalue Estimation Method (Mode Coupling Method) for Small Signal Stability Analysis of Power System
}

\author{
Naoyuki Uchida Member (Tokyo University of Science)
}

Keywords: power system, steady state stability, eigen value, modal analysis, mode coupling method

The estimation method of the eigenvalue with the mode coupling is described in this thesis. This eigenvalue estimation method that the author had developed was named Mode Coupling Method. In small signal stability analysis in the electric power system, the eigenvalue analysis is frequently used. The Mode Coupling Method is a method of estimating the change of the eigenvalue with high degree of accuracy, when the parameter changes.

The author has done various researches on the stability analysis in the power systems so far. The author had developed the small signal stability analysis technique (S method) in the large-scale electric power system, the control system optimization technique for the system stabilization, and the monitoring and the preventive control method of small signal stability. The method of estimating the changes of the eigenvalues due to the parameter changes is important in these studies.

The eigenvalue sensitivity analysis method has been used to estimate the change of the eigenvalue. The eigenvalue sensitivity analysis is a linear estimation of the change of the eigenvalue. However, the eigenvalue shows a nonlinear change frequently. Therefore, the calculation efficiency and the calculation speed were insufficient.

In the Mode Coupling Method, first of all, it searches for the important mode that pays attention and the modes with a strong interaction, strongly related modes.

Next, these two or more modes are coupled and a new eigenvalue of the coupled matrix is calculated those are good estimation of new eigenvalues. The size of the coupled matrix is very small. We can consider mutual interaction between important modes. As a result, it is a powerful method in which nonlinear estimation of the eigenvalue is possible.

The calculation accuracy of the mode coupling method was verified by using IEEJ standard model EAST30. In this power system model, there are 240 eigenvalues.

Figure 1 shows the result of eigenvalues estimation by the MC method, where $\mathrm{n}$ is the total dimension of coupling modes. Fig. 2 shows error of eigenvalues estimated by the MC method. The results show that the MC method will be a powerful tool for fast and accurate eigenvalues estimation.

In general, the QR method is used for the calculation of the eigenvalues. The computing time of the eigenvalue analysis by the $\mathrm{QR}$ method is proportional to the third power of the matrix size. The matrix size used for eigenvalue estimation by the mode coupling method is about $1 / 8$ of the original matrix. Therefore, the computing time of the eigenvalue estimation becomes less than $1 \%$ of the former computing time.

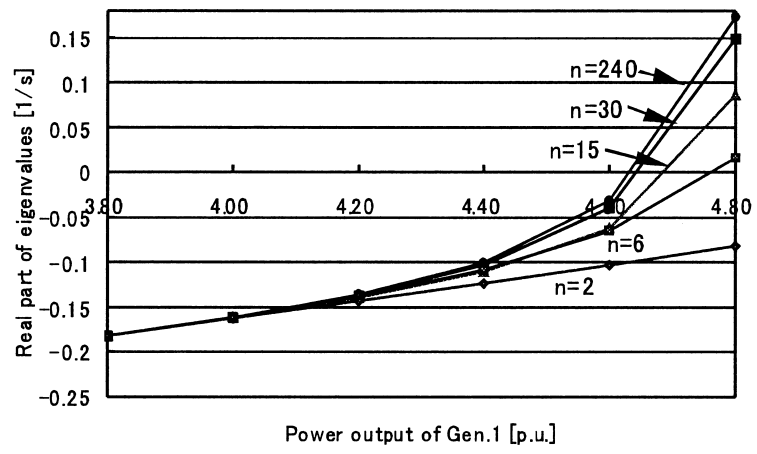

(a) Real part of estimated eigenvalues

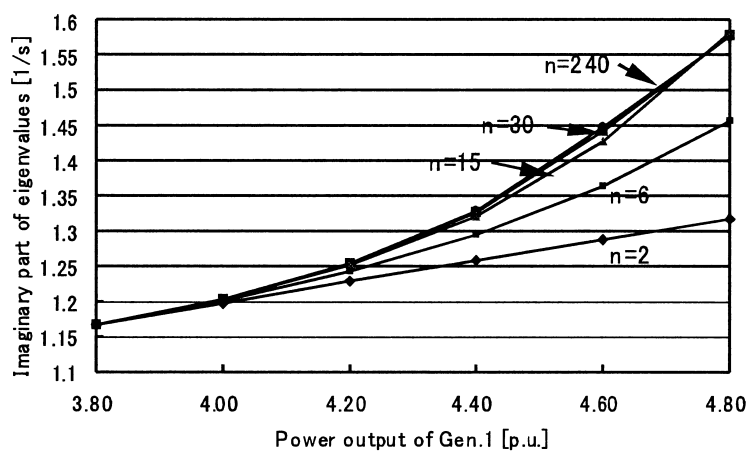

(b) Imaginary part of estimated eigenvalues

Fig. 1. Estimated eigenvalues by MC method

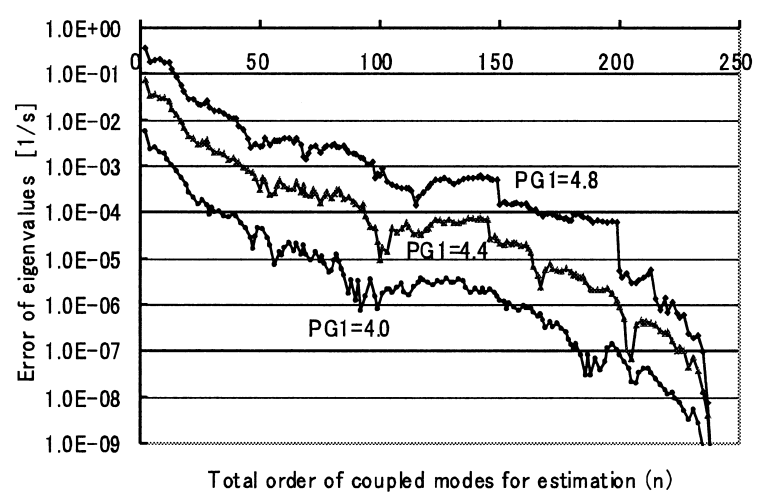

Fig. 2. Error of eigenvalues estimated by MC method 


\title{
電力系統の定態安定度解析の為の 固有值推定法(モード結合法)の開発
}

\author{
正員 内田 直之* \\ Development of an Eigenvalue Estimation Method (Mode Coupling Method) \\ for Small Signal Stability Analysis of Power System \\ Naoyuki Uchida*, Member
}

\begin{abstract}
In this paper Eigenvalue estimation method for small signal stability analysis of the electric power systems is proposed. The developed method is named Mode Coupling Method which is the method for estimating the non-linear change of the eigenvalue for the change of parameter, efficiently. The eigenvalue sensitivity analysis method, which has been used to estimate the change of the eigenvalue, is a linear estimation of the change of the eigenvalue. However, the eigenvalue shows a strong nonlinear change frequently. Therefore, the calculating efficiency and the calculating speed were insufficient by the conventional method. In the Mode Coupling Method, at first, it selects the important and most related modes with the major mode for that we pay attention. Next, these two or more selected modes are coupled and a new eigenvalues of the coupled matrix are calculated, those are good estimation of new eigenvalues. The size of the coupled matrix is very small. We can consider mutual interaction between important modes. As a result, it is a powerful method in which nonlinear estimation of the eigenvalue is possible. When QR method is used, the calculation time which is required for eigenvalue analysis, is proportional to the third power of the size of the matrix. The size of the matrix which is used for Mode Coupling Method, is approximately $1 / 6$ of the origin. Therefore, the computing time for eigenvalues estimation becomes less than $1 \%$ of computing time of the origin. Concerning the computing accuracy of the proposed method, verification was done with IEEJ standard power system model EAST30.
\end{abstract}

キーワード : 電力系統, 定態安定度, 固有值, モード解析, モード結合法

Keywords: power system, steady state stability, eigen value, modal analysis, mode coupling method

\section{1. はじめに}

電力供給コストの低減を進めるためには，送変電線設備 を最大限に利用することが必要であるが，電力系統の安定 限界をより正確に把握しておくことが極めて重要となって いる。

本論文は, 電力系統の定態安定度解析において必要となる 固有值の高精度な推定法を提案している。この手法をモー ド結合法 (Mode coupling method：以下 MC 法と呼ぶ）と 名づけた。一般に系統の各種パラメータが変化すると定態 安定度解析で用いる係数行列が変化し, さらに係数行列の 変化に対して固有值が変化する。係数行列の変化も固有值 の変化も非線形な変化となるが, 係数行列の変化に伴う固 有值の変化は極めて強い非線形性を示すことがある。今回

\footnotetext{
*東京理科大学工学部電気工学科

干 102-0073 東京都千代田区九段北 1-14-6

Faculty of Engineering, Tokyo University of Science

1-14-6, Kudannkita, Ciyoda-ku, Tokyo 102-0073
}

提案する MC 法によってこの非線形な特性を持つ固有值の 変化を精度良く推定することが可能となった。

著者は, これまで, 大規模電力系統の定態安定度解析手法 (S 法) の開発 ${ }^{(1)(2)}$ ，系統安定化のための制御系設計手法の 開発 ${ }^{(3)}$, 定態安定度の監視・予防制御方式の開発 ${ }^{(4)}$ などを 進めてきた。これらの中で, 係数行列の変化に対する固有 值の変化を推定する方法として, 固有值感度解析法が大き な役割を果たしてきた。しかしながら, 固有值感度解析法 は線形推定であるのに対し, 固有值の変化が係数行列の変 化に対し強い非線形性を示すことがある(5)。そのため，パ ラメータの変化に対しその都度, 固有值を再計算する必要 があり，従来の方法で制御系の最適化計算などを行うには 多大な量の計算が必要であった。 MC 法は, 着目するモー ドと, このモードと強い相互作用を持つ複数のモードを選 択しこれらを連結して固有值を求める方法である。これに より固有値の非線形な変化の高精度な推定が可能となった。

固有值の計算に QR 法を用いる場合は，固有值解析の主 要計算部分に要する計算時間が, 行列のサイズのほほ 3 乗 
に比例する。MC 法に用いる行列のサイズは, 元の行列の およそ $1 / 8$ 程度で十分であり，したがって，固有值推定に 要する時間は元の行列の計算時間の $1 \%$ 以下となる。

MC 法の計算精度については, 電気学会標準モデル EAST30 (6) を例題系統として検証を行った。また，連結す べきモードの選定法やその場合の固有值誤差の推定法につ いても検討を行いその有効性を検証することができた。

\section{2. 定態安定度解析}

〈2・1〉 定態安定度とモード解析電力系統の基本方 程式は一般に次の非線形微分方程式で表すことができる。

$$
\dot{\mathbf{x}}=\mathbf{f}(\mathbf{x}, \alpha)
$$

ここで， $\mathbf{x}$ は状態変数べクトル， $\alpha$ は任意のパラメータで ある。

定態安定度解析は (1) 式の平衡点 $\mathbf{x}_{0} \quad(\mathbf{f}(\mathbf{x}, \alpha)=0$ となる 点 $\mathbf{x}=\mathbf{x}_{0}$ ）のまわりで微少変化に対する系統の安定性を論 じるものである。すなわち，次式

$$
\mathbf{x}=\mathbf{x}_{\mathbf{0}}+\Delta \mathbf{x}
$$

で微少変化量 $\Delta \mathbf{x}$ に変数の変換を行い，(1) 式を次の (2) 式

$$
\Delta \dot{\mathbf{x}}=\mathbf{A} \Delta \mathbf{x}
$$

で線形近似し，この線形微分方程式の安定性を問題とする。 ここで行列 $\mathbf{A}$ は次式で表される $\mathrm{n} \times \mathrm{n}$ の行列である。

$$
\mathbf{A}=\left[\frac{\partial \mathbf{f}}{\partial \mathbf{x}}\right]_{\mathbf{x}=\mathbf{x}_{0}}
$$

本論文ではいずれも状態变数の微少変動量に対する線形 微分方程式を基本方程式とするので, 煩雑さを避けるため $\Delta \mathbf{x}$ をあらためて $\mathbf{x}$ と書き直し，次式を基本方程式とする。

$$
\dot{\mathbf{x}}=\mathbf{A x}
$$

ここで， $\mathbf{A}$ の右固有べクトルを並べた行列 $\mathbf{P}$ （以下モー ド行列と呼ぶ）を用いて

$$
\mathbf{x}=\mathbf{P y}
$$

とし，(3) 式を変形すると

$$
\left.\begin{array}{l}
\mathbf{P y}=\mathbf{A P y} \\
\dot{\mathbf{y}}=\mathbf{P}^{-\mathbf{1}} \mathbf{A P y}
\end{array}\right\}
$$

となる。ここで $\mathbf{P}^{-1} \mathbf{A P}$ は行列 $\mathbf{A}$ の固有值 $\left(\lambda_{1}, \lambda_{2}, \ldots \lambda_{n}\right)$ が対角線上に並ぶ対角行列 $\boldsymbol{\Lambda}$ となる。

$$
\mathbf{P}^{-\mathbf{1}} \mathbf{A P}=\boldsymbol{\Lambda}=\left[\begin{array}{cccc}
\lambda_{1} & 0 & \cdots & 0 \\
0 & \lambda_{2} & \cdots & 0 \\
\vdots & \vdots & \ddots & \vdots \\
0 & 0 & \cdots & \lambda_{n}
\end{array}\right]
$$

また行列 $\mathbf{P}^{-1}$ の横ベクトルは行列 $\mathbf{A}$ の左固有ベクトルで ある。
固有值 $\lambda_{i}$ が実数の場合はこの一組の固有值 $\lambda_{i}$ と固有べ クトル $\mathbf{p}_{i}$ のセットをモード $\mathrm{i}$ と呼ぶ。また, 固有值 $\lambda_{i}$ が複 素数の場合はこの固有值 $\lambda_{i}$ と固有ベクトル $\mathbf{p}_{i}$ およびこれ らと夫々共役な固有值 $\lambda_{i+1}$ と固有べクトル $\mathbf{p}_{i+1}$ のセットを モード $(\mathrm{i}, \mathrm{i}+1)$ と呼ぶこととする。ただし，特に混乱を生 じない場合には後者の複素数のモード $(i, i+1)$ も単にモー ド i と呼ぶことにする。

同様に，以下の記述では煩雑さを避け分かりやすさを優 先するため 2 つのモードを関連づけて説明するとき，まず 両モードとも実数のモードの場合についてのみ記述を行う ことにする。どちらかあるいは両者が複素数の場合にも容 易に拡張できるため，その場合の記述は省略する。

$\langle\mathbf{2} \cdot \mathbf{2}\rangle$ 従来の固有值推定法（感度解析法）

(1) 式に おいて, パラメー夕 $\alpha=\alpha_{0}$ が $d \alpha$ だけ無限小の変化をした ときの固有值 $\lambda_{i}$ の変化率すなわち固有值感度は次式で求め ることができる。

$$
\begin{aligned}
& \frac{\partial \lambda_{i}}{\partial \alpha}=\mathbf{q}_{i}\left(\frac{\partial \mathbf{A}}{\partial \alpha}{ }_{\alpha=\alpha_{0}}\right) \mathbf{p}_{i} \ldots \ldots \ldots \ldots \ldots \ldots \ldots \ldots \ldots \\
& \text { ここで } \mathbf{q}_{i} \text { は左固有ベクトルであり，その大きさは }
\end{aligned}
$$

$$
\mathbf{q}_{i} \cdot \mathbf{p}_{i}=1
$$

となるよう規格化しておくこととする。

この固有值感度を利用すれば， $\alpha=\alpha_{0}$ が $\tilde{\alpha}=\alpha_{0}+\Delta \alpha$ に 変化したことによって， $\mathbf{A}$ が

$$
\tilde{\mathbf{A}}=\mathbf{A}+\Delta \mathbf{A}
$$

に変化したとき, 次式によって固有值の変化 $\Delta \lambda_{i}$ を推定す ることが出来る。

$$
\Delta \lambda_{i}=\mathbf{q}_{i}(\Delta \mathbf{A}) \mathbf{p}_{i}
$$

(8) 式による推定は $\Delta \lambda_{i}$ と $\Delta \mathbf{A}$ の間に線形の関係が成り 立っていることを前提としているので, 線形推定法と呼ぶ こともできる。

\section{3. モードカップリング法（MC 法）による固有值の 非線形推定}

〈3・1〉 モードカップリング（MC）法＼cjkstart行列 $\mathbf{A}$ が (8) 式のように変化したとき行列 $\tilde{\mathbf{A}}$ に $\mathbf{A}$ の固有ベクトルから なるモード行列 $\mathbf{P} に よ る$ 相似変換を行うと次式となる。

$$
\begin{aligned}
& \quad=\Lambda+\Delta \Lambda \\
& \text { ここで } \\
& \Delta \Lambda=\mathbf{P}^{-1} \Delta \mathbf{A P}
\end{aligned}
$$$$
\mathbf{P}^{-1} \tilde{\mathbf{A}} \mathbf{P}=\mathbf{P}^{-1}(\mathbf{A}+\Delta \mathbf{A}) \mathbf{P}
$$$$
=\mathbf{P}^{-1} \mathbf{A} \mathbf{P}+\mathbf{P}^{-1} \Delta \mathbf{A P}
$$

とおいた。

$(\boldsymbol{\Lambda}+\Delta \boldsymbol{\Lambda})$ は相似変換で得られる行列である。従って, そ の固有值は元の行列 $\tilde{\mathbf{A}}$ の固有值と厳密に一致する。 
ここで，行列 $(\boldsymbol{\Lambda}+\Delta \boldsymbol{\Lambda})$ の近似を考える。行列 $\Delta \boldsymbol{\Lambda}$ のす べての要素は一般に非零であり, 非対角要素はモード間の 相互作用を表すが，〈2·2〉節で示した従来の線形推定法は $\Delta \boldsymbol{\Lambda}$ の要素 $\Delta \lambda_{i j}$ のうち非対角要素を全て 0 として近似した ものである。すなわち，モード間の相互作用を全く無視し た場合と同等であることが分かる。

そこで，もう少し良い近似を考える。例えば，以下の例 のように着目するモードをモード $(2,3)$ とし，このモード と強い相互作用を示すモードをモード $(6,7)$ とすれば，こ れら 2 個のモードに対応する非対角要素 $\Delta \lambda_{i j}$ を残しそれ以 外の非対角要素を 0 とすれば，従来の線形推定法と比べて, 従来法より高い精度で固有值の推定ができると予想できる。

$$
\left[\begin{array}{ccccccccc}
\Delta \lambda_{11} & 0 & 0 & 0 & 0 & 0 & 0 & \cdots & 0 \\
0 & \Delta \lambda_{22} & \Delta \lambda_{23} & 0 & 0 & \Delta \lambda_{26} & \Delta \lambda_{27} & \cdots & 0 \\
0 & \Delta \lambda_{32} & \Delta \lambda_{33} & 0 & 0 & \Delta \lambda_{36} & \Delta \lambda_{37} & \cdots & 0 \\
0 & 0 & 0 & \Delta \lambda_{44} & 0 & 0 & 0 & \cdots & 0 \\
0 & 0 & 0 & 0 & \Delta \lambda_{55} & 0 & 0 & \cdots & 0 \\
0 & \Delta \lambda_{62} & \Delta \lambda_{63} & 0 & 0 & \Delta \lambda_{66} & \Delta \lambda_{67} & \cdots & 0 \\
0 & \Delta \lambda_{72} & \Delta \lambda_{73} & 0 & 0 & \Delta \lambda_{76} & \Delta \lambda_{77} & \cdots & 0 \\
\vdots & \vdots & \vdots & \vdots & \vdots & \vdots & \vdots & \ddots & \vdots \\
0 & 0 & 0 & 0 & 0 & 0 & 0 & \cdots & \Delta \lambda_{n n}
\end{array}\right]
$$

非零の非対角要素が左上に集まるようにこの行列の行と 列を並べ替えると，この例では以下の行列となる。

$$
\left[\begin{array}{ccccccccc}
\Delta \lambda_{22} & \Delta \lambda_{23} & \Delta \lambda_{26} & \Delta \lambda_{27} & 0 & 0 & 0 & \cdots & 0 \\
\Delta \lambda_{32} & \Delta \lambda_{33} & \Delta \lambda_{36} & \Delta \lambda_{37} & 0 & 0 & 0 & \cdots & 0 \\
\Delta \lambda_{62} & \Delta \lambda_{63} & \Delta \lambda_{66} & \Delta \lambda_{67} & 0 & 0 & 0 & \cdots & 0 \\
\Delta \lambda_{72} & \Delta \lambda_{73} & \Delta \lambda_{76} & \Delta \lambda_{77} & 0 & 0 & 0 & \cdots & 0 \\
0 & 0 & 0 & 0 & \Delta \lambda_{11} & 0 & 0 & \cdots & 0 \\
0 & 0 & 0 & 0 & 0 & \Delta \lambda_{44} & 0 & \cdots & 0 \\
0 & 0 & 0 & 0 & 0 & 0 & \Delta \lambda_{55} & \cdots & 0 \\
\vdots & \vdots & \vdots & \vdots & \vdots & \vdots & \vdots & \ddots & \vdots \\
0 & 0 & 0 & 0 & 0 & 0 & 0 & \cdots & \Delta \lambda_{n n}
\end{array}\right]
$$

この場合には着目するモードの新しい固有值の推定值を 得るためには, $4 \times 4$ の行列の固有值を求めれば良いことに なる。

一般的に記述すれば以下のとおりである。正確に求めた いモード，これを着目モードと呼ぶことにするが，これを モード i とする。着目モードが複数個あっても容易に拡張 することができるので，ここでは，説明を複雑にしないため 着目モードを 1 個としておく。この着目モード $\mathrm{i} に$ 強い相 互作用を持つ，すなわち強い影響を与えるモードを選択し 連結する。これらの強い影響を与えるモードを強相関モー ドと呼ぶこととする。この強相関モードが $\mathrm{j}_{1}, \mathrm{j}_{2}, \ldots \mathrm{j}_{\mathrm{m}}$ の $\mathrm{m}$ 個あるとする。着目モードと $\mathrm{m}$ 個の強相関モードに対応 する非対角要素 $\Delta \lambda_{i j}$ だけを残しそれ以外の非対角要素を 0
として近似すれば固有值のより良い推定值をわずかな計算 量で求められることが期待できる。このことは後に示す数 值例で明らかにされた。この固有值推定法をモード結合法 (Mode Coupling Method）と呼ぶことにする。本稿では以 下 MC 法と記す。

$\langle\mathbf{3} \cdot \mathbf{2}\rangle \quad$ 強相関モードの選択法 上記の強相関モード の選択法は検討課題の一つである。ここではモード ij 間の 影響度 $d_{i j}(j=1, \ldots, n, j \neq i)$ を求め, $d_{i j}$ のうち大きい方 から $\mathrm{m}$ 個のモード $\mathrm{j}_{1}, \mathrm{j}_{2}, \ldots \mathrm{j}_{\mathrm{m}}$ を選ぶことにする。モード 間の影響度の算定法としては以下の 2 つ方法を示す。こ の両者の比較については後述の数值計算例で示す。

（1）算定法 1（2モードの連結を用いる方法）いま 着目モードをi とする。モード $\mathrm{i}$ と $\mathrm{j}$ の両モードを結合して 固有值を求める。すなわち次の行列の固有值を求める。

$$
\mathbf{M}_{i j}=\left[\begin{array}{cc}
\lambda_{i}+\Delta \lambda_{i i} & \Delta \lambda_{i j} \\
\Delta \lambda_{j i} & \lambda_{j}+\Delta \lambda_{j j}
\end{array}\right]
$$

$\mathbf{M}_{i j}$ の固有值のうち $\left(\lambda_{i}+\Delta \lambda_{i i}\right)$ に対応する固有值を $\mu_{i j}$ と する。モード $\mathrm{i} と \mathrm{j}$ を結合したことにより生じる推定固有 值の差の絶対值

$$
d_{i j}^{(1)}=\left|\left(\lambda_{i}+\Delta \lambda_{i i}\right)-\mu_{i j}\right| \cdot
$$

をモード ij 間のモード間影響度として用いる。

なお煩雑さを避けるため両モードとも実数の固有值の場 合について説明を行ったが複素数の場合にも共役となる要 素を考慮して容易に拡張できるので省略する。その場合に は組み合わせによって行列 $\mathbf{M}_{i j}$ が $3 \times 3$ あるいは $4 \times 4$ の 行列となる。

（2）算定法2（非対角要素の積を用いる方法） 着目

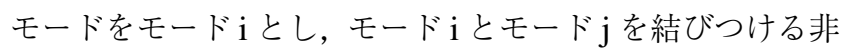
対角要素である $\Delta \lambda_{i j}$ と $\Delta \lambda_{j i}$ の積の絶対值

$$
d_{i j}^{(2)}=\left|\Delta \lambda_{i j} \times \Delta \lambda_{j i}\right| \text {. }
$$

をモード ij 間の影響度として用いる。

$\langle\mathbf{3} \cdot \mathbf{3}\rangle$ 推定固有值の誤差の推定值 $\quad(A+\Delta A)$ の真の 固有值が不明な状態で提案法による推定固有值について発 生する誤差の概略值をあらかじめ知ることができれば，連 結すべきモードを何個選べば十分であるかの判断を事前に 行うことができる。

ここでは，算定法 1 （2 モードを連結する方法）によ る誤差の推定法を提案する。算定法 1 で得られる $d_{i j}^{(1)}=$ $\left|\left(\lambda_{i}+\Delta \lambda_{i i}\right)-\mu_{i j}\right|$ の值はモード $\mathrm{j}$ を連結しなかったときに発 生する誤差の大きさを概略示したものと考えることができ る。全体で L 個のモードがあり, 着目モードを除く L-1 個の モードのうち $d_{i j}^{(1)}$ の大きい方から $\mathrm{m}$ 個のモード $\mathrm{j}_{1}, \mathrm{j}_{2}, \ldots \mathrm{j}_{\mathrm{m}}$ を選ぶとする。このとき発生する誤差は, $\mathrm{L}-\mathrm{m}-1$ 個の連 結されなかったモードによる誤差と考えることが出来るの で次式の $E_{s}(m)$ を誤差の概略推定值とすることができる。

$$
E_{s}(m)=\sum_{j=m+1}^{L-1} d_{i j}^{(1)}
$$




\section{4. 数值計算例}

〈4・1〉モデル系統と解析条件電気学会 EAST30 (peak) 標準モデル系統 ${ }^{(6)}$ を用いて, 潮流の変化に伴う固 有值の変化を本推定法により推定しその精度について検討 を行った。潮流はノード番号 2001 に接続されている発電 機 1 番 (G1) の出力 PG1 をベースケースの 3.8 p.u. から最 大 4.8 p.u. まで 0.2 p.u. ずつ増加し, 各ケースについて提案 法による推定固有值を求め真の固有值との比較を行った。 スイング発電機は発電機 25 番（ノード番号 3010）とし, ここで変化分を吸収させた。発電機モデルは界磁巻線及び $\mathrm{d}, \mathrm{q}$ 軸に制動巻線を各 1 個とした 3 次の Park 式にロータ の運動方程式を含めて 5 次の微分方程式とし, AVR は直流 励磁機方式の 3 次の標準定数モデル $(\mathrm{Lat}=1)$ とした。ガ バナタービンモデルは省略し機械入力は一定とした。従っ て 1 機あたり 8 次の微分方程式となり全系では 240 次の微 分方程式となる。

なお, PG1 = 4.8 p.u. では系統の定態安定度が不安定と なった。表 1 に, 各ケースでのこの系統の固有值を示した。 これは系統の最も周期が長く不安定となりやすい振動モー ドの固有值であり，主動摇モードと呼ぶべきモードである が，この主動摇モードを本解析における着目モードとした。

提案法による固有值の推定はベースケースで求めた固有 ベクトルを用いて行った。また潮流計算および $\mathrm{A}$ 行列の計 算については線形近似などにより簡略計算することはせず, すべてのケースで厳密計算を行った。

図 1 に算定法 1 （2 モードを連結する方法）を用いて計 算した着目モード $\mathrm{i}$ に対するモード $\mathrm{j}$ のモード間影響度の 大きさ $d_{i j}^{(1)}$ を示す。図の横軸はモード番号でありモード間 影響度の大きい順番に並べ直してある。また， 3 本の曲線 は PG1 = 4.0, 4.4, 4.8 [p.u.] の各ケースに対応している。

\section{$\langle\mathbf{4} \cdot \mathbf{2}\rangle$ 解析結果}

（1）推定固有值の精度 図 2 にC 法による着目 モードの推定固有值を示す。横軸 PG1 は G1 の有効電力出 力であり, パラメータの $\mathrm{n}$ は推定に用いたモードの総次数で ある。すなわち着目モードと強相関モードで, 複素数モー ドの次数を 2 , 実数のモードの次数を 1 としたときの次数

表 1 電気学会 East30 標準系統モデルにおける 主動摇モードの固有值

Table 1. Major Eigenvalue of the major mode of IEEJ East 30 power system model.

\begin{tabular}{|c|c|c|}
\hline PG1 [p.u]. & $\operatorname{Real}(\lambda)[1 / \mathrm{s}]$ & $\operatorname{Imag}(\lambda)[1 / \mathrm{s}]$ \\
\hline 3.80 (ベース) & -0.18175 & 1.16627 \\
\hline 4.00 & -0.16110 & 1.20336 \\
\hline 4.20 & -0.13583 & 1.25424 \\
\hline 4.40 & -0.10054 & 1.32856 \\
\hline 4.60 & -0.03158 & 1.44702 \\
\hline 4.80 & 0.17272 & 1.57589 \\
\hline
\end{tabular}

の総和である。 $\mathrm{n}=2$ のときは着目モードのみを用いて推 定した場合, すなわち従来の固有值感度による線形推定法 を用いた場合である。また, $\mathrm{n}=240$ のときは固有值の厳密 解と完全に一致する。PG1 = 4.0 p.u. では線形推定法でも それほど大きな誤差は生じないが, PG1 = 4.6p.u. 以上では 非線形性が強く線形推定では大きな誤差となる。MC 法で は $\mathrm{n}=6$ でも大幅な改善がなされており, $\mathrm{n}=30$ (元の次数 の $1 / 8$ ）で実用上支障が無い程度に精度が改善されている。

図 3 に推定固有值の誤差を示す。横軸は推定に用いた モードの総次数 $\mathrm{n}$ である。PG1 が大きいほど誤差は大きく なるが, $\mathrm{PG} 1=4.8$ の場合でも $\mathrm{n}=30$ 程度とすれば誤差が $1 \%$ 程度になることが分かる。

$\langle\mathbf{4} \cdot \mathbf{3}\rangle \quad$ 強相関モードの選択法の比較 $\langle 3 \cdot 2\rangle$ 節に示し

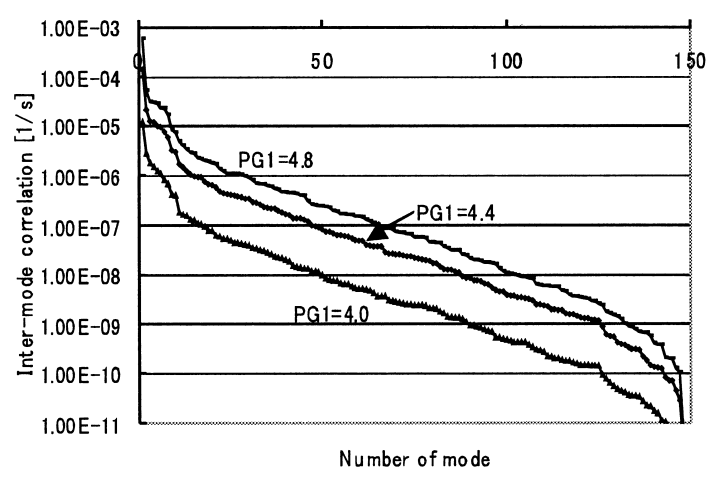

図 1 モード間影響度

Fig. 1. Inter-mode correlation.

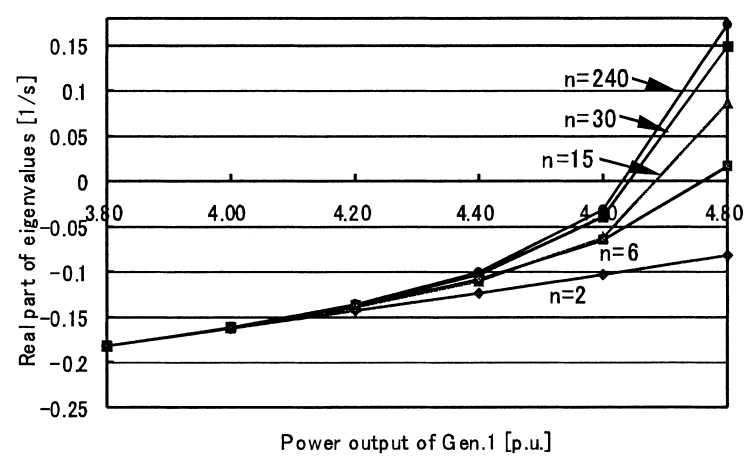

(a) Real part of estimated eigenvalues

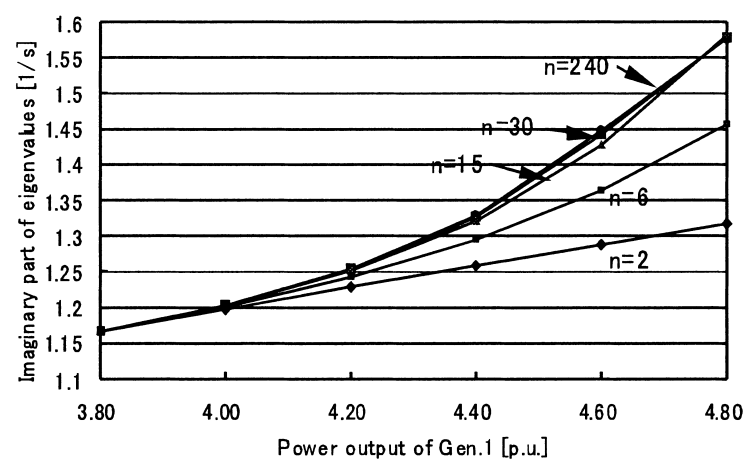

(b) Imaginary part of estimated eigenvalues

図 $2 \mathrm{MC}$ 法による推定固有值

Fig. 2. Estimated eigenvalues by MC method. 


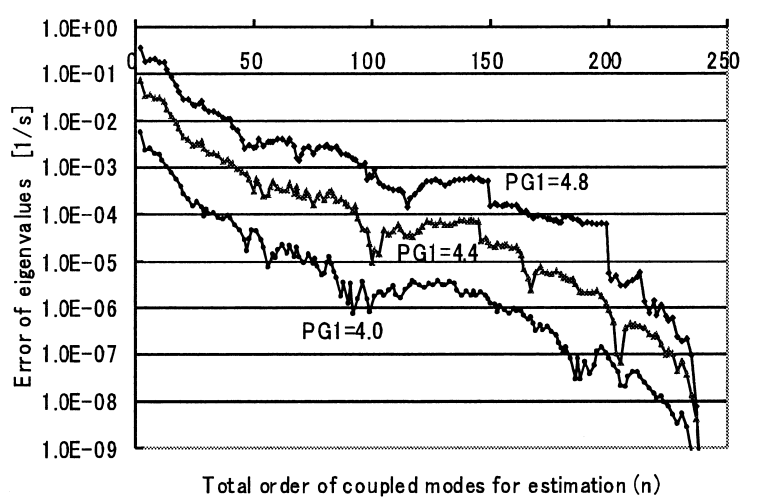

図 $3 \mathrm{MC}$ 法による推定固有值の誤差

Fig. 3. Error of eigenvalues estimated by MC method.

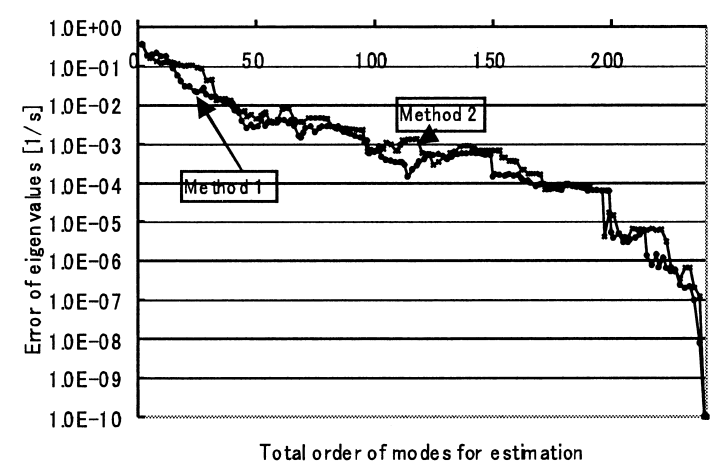

図 4 強相関モードの選択法の比較

Fig. 4. Comparison of selection of coupling modes.

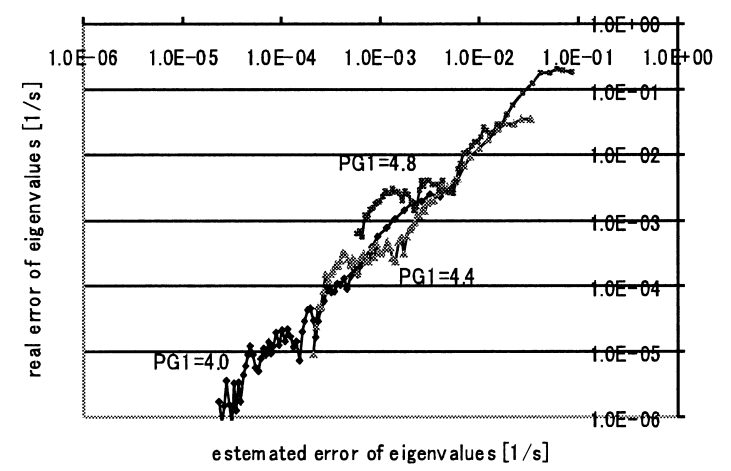

図 5 固有值の実際の誤差と推定誤差

Fig. 5. True error and estimated error of eigenvalues.

た強相関モードを選択する際に用いる影響度を算定する 2 つの方法（算定法 1 と算定法 2) について得られる推定固 有值の誤差の比較を行った結果を図 4 に示す。両手法によ る誤差の違いは僅かではあるが, 算定法 1 がいくらか勝っ ている。

また，算定法 1 の場合には誤差の推定值を容易に推定でき るメリットがある。図 5 に推定固有值の誤差について (16) 式による概略推定值と実際に発生した誤差の相関を示した。 両者には十分な相関があり(16) 式による誤差の推定法が有 用かつ有効であることが分かる。

〈4・4〉 計算時間について ここでは MC 法を用いた 場合の計算時間について考察を行う。固有值計算に QR 法
表 2 固有值計算に要する CPU 時間

Table 2. CPU time for computing eigenvalues.

\begin{tabular}{|c|c|c|c|}
\hline Matrix size $\mathrm{n}$ & 16 & 80 & 240 \\
\hline CPU time [ms] & 0.46 & 15.15 & 303.9 \\
\hline Time ratio [\%] & 0.2 & 5.0 & 100.0 \\
\hline
\end{tabular}

を用いると，最も計算時間を必要とする演算部分は行列の サイズ nの 3 乗に比例すると言われている。実際には $\mathrm{n} に$ 比例する計算や $\mathrm{n}$ の 2 乗に比例する部分などがあるためも う少し計算時間の短縮効果は小さくなる。表 2 に計測した 值を示したが，この例では CPU 時間は 2.4 乗から 2.7 乗に 比例する程度であることが分かる。

今回のモデル系統であれば PG1 = 4.8 p.u. の場合が最も 推定誤差が大きいが，この場合にも $\mathrm{n}=30$ 程度で固有值の 推定を行えば数 $\mathrm{ms}$ で $1 \%$ 以内の誤差で固有值の計算が可能 である。

なお，今回プログラム言語としては The MathWorks 社の Matlab 用いた。CPU は Pentium4 の $3.0 \mathrm{Ghz}$ である。

\section{5. おわりに}

本稿では固有值の効率的な推定法であるモードカップリ ング法（MC 法）を提案し，モデル系統によりその計算精 度の検証を行った結果を示した。また，結合すべきモード の選択方法についても提案を行った。計算結果はいずれも 満足できる精度と効率の高さを示したものであった。今後 は, 安定度の監視・予防制御, 制御系の設計などへの本提 案手法の多様な応用が考えられる。

最後に，本手法の検証などを手伝ってくれた本学修士 2 年鮫島泰希君に感謝の意を表す。

(平成 20 年 6 月 10 日受付，平成 20 年 7 月 17 日再受付)

$$
\text { 文献 }
$$

（1）内田直之：「新しい固有值解法による電力系統の動的定態安定度解 析」, 電学論 B, Vol.100, No.7, pp.17-24 (1980-7)

(2) N. Uchida and T. Nagao: "A New Eigen-Analysis Method of Steady-State Stability Studies for Large Power Systems: S Matrix Method", IEEE Trans. PAS, Vol.PWR-3, No.2, pp.706-714 (1988)

（3）吉村健司・内田直之：「多機系統ロバスト安定化のための P $+\omega$ 形 PSS 定数最適設計手法」, 電学論 B, Vol.118-B, No.11, pp.1312-1320 (1998-11)

（4）内田直之・高崎昌洋・吉村健司:「電力系統の安定運用のための予防 制御論理（その 2)一固有值感度による予防制御の基本論理一」, 電中 研研究報告, T86039 (1986)

（5）柿本義一・内田直之：「定態安定限界近傍に掞ける動摇現象」, 電中 研研究報告, 185010 (1985)

（6）「電力系統の標準モデル」, 電気学会技術報告, No.898 (1999)

内 田 直 之 (正員) 1978 年 3 月東京大学大学院博士課程修了

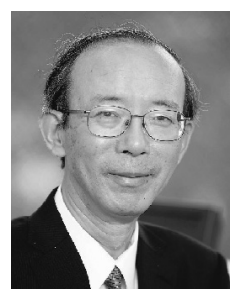
(電気工学専攻)。同年 4 月 (財) 電力中央研究所 入入所。2000 2003 年東北大学客員教授。2002 年 4 月より東京理科大学工学部電気工学科教授 (現職)。主として, 電力系統の解析・計画・運用· 制御に関する研究に従事。工学博士。1988 年電 気学会論文賞受賞。IEEE シニア会員。 